(C) 2020, The Authors. Published by FASS Inc. and Elsevier Inc. on behalf of the American Dairy Science Association ${ }^{\circledR}$. This is an open access article under the CC BY-NC-ND license (http://creativecommons.org/licenses/by-nc-nd/4.0/).

\title{
Effect of subclinical and clinical hypocalcemia and dietary cation-anion difference on rumination activity in periparturient dairy cows
}

\author{
J. P. Goff, ${ }^{1 *} \oplus$ A. Hohman, ${ }^{1}$ and L. L. Timms ${ }^{2}$ \\ ${ }^{1}$ College of Veterinary Medicine, lowa State University, Ames 50011 \\ ${ }^{2}$ Animal Science Department, College of Agriculture and Life Sciences, lowa State University, Ames 50011
}

\begin{abstract}
Rumination involves a complex series of muscle contractions that bring a bolus of ingesta to the mouth for further mastication before it is swallowed again. Healthy cows ruminate 8 to $9 \mathrm{~h} / \mathrm{d}$. Hypocalcemia is known to disrupt nerve and muscle function. Our hypothesis was that hypocalcemia in periparturient cows would reduce rumination activity. Twenty-six Holstein cows entering their third lactation or greater were fed a control diet [dietary cation-anion difference (DCAD) = $+196 \mathrm{mEq} / \mathrm{kg}$ of dry matter (DM)] or a low DCAD diet supplemented with anions (DCAD $=-9 \mathrm{mEq} / \mathrm{kg}$ of DM) prepartum. Periparturient plasma Ca concentration and rumination rate were determined. Four of 12 control cows developed clinical milk fever, necessitating intravenous Ca therapy. Rumination rate decreased in all cows around the time of calving. Rumination rate on the first and second day of lactation was highly correlated with the cow's plasma Ca concentration on the first day of lactation. In one of our statistical models, a normocalcemic cow was defined as a cow whose plasma $\mathrm{Ca}$ concentration remained above $2.00 \mathrm{mM}$. Cows were retrospectively classified as normocalcemic, subclinically hypocalcemic, or clinically hypocalcemic (milk fever). Only 4 cows were considered normocalcemic, and all had been fed the low DCAD diet. Normocalcemic cows spent more time ruminating on the first day after calving than subclinically hypocalcemic cows or cows with milk fever. Cows with milk fever had a lower rumination rate than normocalcemic cows through $d$ 3 of lactation. Rumination activity in cows with milk fever was almost nondetectable in the hours before and after intravenous Ca treatment for an extended period, despite the return of muscle function that allowed the cows to stand and eructate following treatment. Other
\end{abstract}

Received September 11, 2019.

Accepted November 23, 2019.

*Corresponding author: jpgoff55@gmail.com statistical models using different definitions of normocalcemia gave qualitatively similar results. Diet had a great effect on plasma Ca concentration and rumination rate. Even when cows with clinical milk fever were removed from the control cow data set, cows on the low DCAD diet had significantly greater plasma Ca concentrations in the first $36 \mathrm{~h}$ after calving and a higher rumination rate on $\mathrm{d} 1$ of lactation $(248 \pm 26 \mathrm{~min})$ than control cows (158 $\pm 32 \mathrm{~min})$.

Key words: hypocalcemia, rumination, milk fever, dietary cation-anion difference (DCAD)

\section{INTRODUCTION}

Rumination consists of regurgitation of forage particles and ingesta from the rumen into the mouth to allow for chewing and reduction of particle size before swallowing (Van Soest, 1994). Healthy cows typically spend 460 to $540 \mathrm{~min} / \mathrm{d}$ ruminating (Bae et al., 1983; SCR Research, 2013; Stangaferro et al., 2016). Rumination involves the tongue, pharynx, esophagus, and rumen/reticulum. Their coordinated movement requires visceral sensory afferent nerves to signal the presence of the rumen forage raft to the medullary brain and cortex. The muscles involved in regurgitation are then activated (Stevens and Sellers, 1959; Ruckebusch, 1989). The striated musculature of the tongue, pharynx, and esophagus in ruminants is under some degree of voluntary control mediated by cranial nerves (tongue and pharynx) and vagal parasympathetic activation of enteric nervous system fibers (esophagus). Forestomach motility is controlled primarily by parasympathetic tone of the vagus nerve. As well, neurons exhibit a degree of autonomous control of motility in the myenteric plexus of the esophagus and rumen (Pfannkuche et al., 2002).

Extracellular $\mathrm{Ca}$ inhibits entry of $\mathrm{Na}$ into nerve cells through voltage-gated $\mathrm{Na}$ channels. During hypocalcemia, the uninhibited entry of $\mathrm{Na}$ into the neurons increases neuronal excitability (Han et al., 2015). This can cause nerves to initiate action potentials without 
provocation at times when they should be in the resting state, interfering with coordinated reflex generation (Castilla-Guerra et al., 2006).

Muscle is also affected by hypocalcemia. In smooth muscle, the stimuli that initiate contraction, such as acetylcholine released by post-ganglionic parasympathetic fibers, cause Ca channels to open in the sarcolemma of smooth muscle fibers. Extracellular Ca moves into the cytosol and binds calmodulin. The Ca-calmodulin complex binds to myosin light chain kinase to initiate contraction. Hypocalcemia reduces the strength and speed of smooth muscle contraction (Webb, 2003). In skeletal muscle, the amount of acetylcholine released from motor neurons in response to action potentials is reduced if extracellular Ca concentration is lower than normal. This reduces the strength of contraction of skeletal muscles.

Rumen smooth muscle contraction ceases when blood ionized Ca concentrations fall to $0.6 \mathrm{mM}$, equivalent to a total blood Ca concentration of $\sim 1.3 \mathrm{mM}(5.3 \mathrm{mg} /$ dL; Jørgensen et al., 1998). Hansen et al. (2003) intravenously administered the Ca-binding agent $\mathrm{Na}$ EDTA to cows to decrease blood ionized Ca concentration. Feed intake decreased linearly with the decline in ionized Ca concentration. The authors also observed time spent chewing during eating, and the number of rumination episodes decreased as well. They concluded that subclinical hypocalcemia depressed feed intake and rumination activity in dairy cows.

Rumen motility can be auscultated using a stethoscope in the left paralumbar fossa or by placing pressure transducers in the rumen. Motility is an involuntary aspect of rumination that is often restored to normal rate and strength following administration of intravenous Ca to the cow with milk fever (Daniel, 1983). However, complete rumination activity - which also involves central nervous system input to coordinate retrograde propulsion of the forage bolus up the esophagus and into the mouth for chewing - may not be fully restored. Rumination monitoring systems have been developed in recent years that use accelerometers to gauge rumination activity by detecting movements associated with mastication. The purpose of this study was to determine whether hypocalcemia affected rumination activity in older periparturient Holstein cows fed a high or low DCAD diet to increase or reduce periparturient hypocalcemia.

\section{MATERIALS AND METHODS}

All procedures performed on the cows in this study were approved by the Iowa State University Institutional Animal Care and Use Committee. Twenty-six cows entering their third lactation or greater, expected to calve between October 10, 2017, and January 7, 2018, were assigned to either a control diet (no anion supplemented; DCAD $=+196 \mathrm{mEq} / \mathrm{kg}$ of $\mathrm{DM})$ or a low DCAD diet (anion supplemented; DCAD $=-9$ $\mathrm{mEq} / \mathrm{kg}$ of $\mathrm{DM}$ ), based on parity and expected calving date. The diets were expected to result in a range of plasma Ca concentrations. In our previous studies (Goff et al., 1989; Goff and Koszewski, 2018), cows fed a high DCAD diet had a plasma Ca concentration the day after calving of $\sim 1.88 \pm 0.4 \mathrm{~m} M$ [mean \pm standard deviation (SD)]. In our calculations to determine the number of cows needed for the study, we determined that a low DCAD diet would need to improve plasma Ca to $2.25 \pm 0.4 \mathrm{~m} M$ to be considered successful. Using an $\alpha$ error level of 0.05 and desiring that statistical power exceed $85 \%$, we concluded that at least 12 cows would be required for each diet treatment.

Diets were composed primarily of corn silage and wheat straw (Table 1). The low DCAD supplement used hydrochloric acid added to a carrier of sunflower meal, rice hulls, limestone, and $\mathrm{MgO}$ as the source of anion (Non-GMO Soychlor; Landus Cooperative, Ames, IA). The control supplement used the same carrier but was prepared with no added hydrochloric acid (Landus Cooperative). Forage nutrient composition was determined 8 wk before the first cow calved, and 4 and 9 wk after. The samples were dried overnight at $60^{\circ} \mathrm{C}$ to determine moisture content before being sent to a commercial laboratory. Forage analysis included wet chemistry for protein fractions, structural carbohydrates, minerals (including sulfur and chloride), fat, starch, and calculated $\mathrm{NE}_{\mathrm{L}}$ (CPM Plus Analysis, Cumberland Valley Analytical Services, Waynesboro, PA). The nutrient composition for each diet presented in Table 1 was calculated using the mean nutrient composition of the forage analyses along with the nutrient specifications supplied by the manufacturers of the concentrates, vitamins, and minerals. The amount of corn silage added to the feed mixer was adjusted based on moisture content determined by farm staff. The other forages and diet components were from single large batches bought for the study and protected under a roof. Dry matter contents of offered diet and orts were determined every 4 wk to allow for calculation of daily DMI. At 4 wk before their expected calving date, cows were moved into a maternity area bedded with corn stover that provided a minimum of $11 \mathrm{~m}^{2}$ of lying space per cow. Cows were fed their respective diets behind Calan gates that were set $76 \mathrm{~cm}$ apart (American Calan, Northwood, NH). All cows had experience eating behind Calan gates in earlier lactations. All cows were permitted at least $3 \mathrm{~d}$ to acclimate to their respective Calan gate and diet before 
feed intake data were recorded. All cows had at least 14 $\mathrm{d}$ of diet DMI recorded before calving. Each cow was offered $\sim 17 \mathrm{~kg}$ (DM) of the appropriate prepartal diet, and refused feed was weighed back daily. After calving on the bedded pack, cows were milked in an adjacent barn and returned to the maternity area for the first 5 $\mathrm{d}$ of lactation. After the first milking, which was within $5 \mathrm{~h}$ of calving, all cows were switched to the lactation diet fed to the Iowa State dairy herd. Each cow was offered $\sim 23 \mathrm{~kg}$ of DM/d of the lactation diet fed behind the same Calan gate used by that cow before calving, and the cow remained housed in the same corn-stoverbedded pen she had calved in. We determined DMI for each cow until d 5 of lactation. After d 5 of lactation, cows were moved to a fresh cow pen not equipped with Calan gates in a freestall barn until they were $10 \mathrm{~d}$ in lactation. This pen ensured at least $76 \mathrm{~cm}$ of bunk

Table 1. Composition of diets fed to cows for the final 4 wk of gestation

\begin{tabular}{|c|c|c|}
\hline Component & Control & $\begin{array}{l}\text { Low } \\
\text { DCAD }\end{array}$ \\
\hline \multicolumn{3}{|l|}{ Ingredient ( $\%$ of DM) } \\
\hline Corn silage & 50.9 & 51.1 \\
\hline Wheat straw & 23.7 & 24.1 \\
\hline Expeller's soymeal $^{1}$ & 3.7 & 3.7 \\
\hline $\begin{array}{l}\text { Soybean meal, solvent, } 48 \% \\
\text { protein }\end{array}$ & 5.4 & 5.4 \\
\hline Legume hay & - & 5.2 \\
\hline Molasses, beet sugar & 1.1 & 1.1 \\
\hline Vitamin ADE, minerals ${ }^{2}$ & 2.13 & 2.13 \\
\hline Anion supplement ${ }^{3}$ & 0 & 7.3 \\
\hline Control supplement ${ }^{4}$ & 7.3 & 0 \\
\hline \multicolumn{3}{|l|}{ Analysis (\% of DM) } \\
\hline $\mathrm{CP}$ & 11.7 & 11.8 \\
\hline NDF (forage NDF) & $44.8(41.6)$ & $44.8(41.6)$ \\
\hline $\mathrm{ADF}$ & 32.2 & 32.1 \\
\hline NFC & 37 & 36 \\
\hline Crude fat & 2.6 & 2.6 \\
\hline $\mathrm{NE}_{\mathrm{L}}(\mathrm{Mcal} / \mathrm{kg})$ & 1.41 & 1.41 \\
\hline $\mathrm{Ca}$ & 0.66 & 0.65 \\
\hline $\mathrm{Mg}$ & 0.47 & 0.46 \\
\hline $\mathrm{P}$ & 0.25 & 0.24 \\
\hline $\mathrm{K}$ & 1.24 & 1.25 \\
\hline $\mathrm{Cl}$ & 0.22 & 0.93 \\
\hline $\mathrm{Na}$ & 0.09 & 0.09 \\
\hline $\mathrm{S}$ & 0.17 & 0.17 \\
\hline $\mathrm{DCAD}^{5}(\mathrm{mEq} / \mathrm{kg})$ & +196 & -9 \\
\hline $\mathrm{MP}^{6}(\mathrm{~g} / \mathrm{d})$ & 1,072 & 1,076 \\
\hline Predicted absorbed $\mathrm{Ca}^{7}(\mathrm{~g} / \mathrm{d})$ & 45 & 46 \\
\hline
\end{tabular}

${ }^{1}$ SoyPlus, Landus Cooperative (Ralston, IA).

${ }^{2}$ Supplied 110,000 IU of vitamin A, 35,000 IU of vitamin D, and 2,500 IU of vitamin E per day and met or exceeded NRC (2001) requirements for trace minerals.

${ }^{3}$ SoyChlor, Non-GMO, Landus Cooperative.

${ }^{4}$ Sunflower meal, rice hulls, limestone, and magnesium oxide (similar to Soychlor, Non-GMO except that no hydrochloric acid was included; Landus Cooperative).

${ }^{5} \mathrm{DCAD}=(\mathrm{mEq} \mathrm{Na}+\mathrm{mEq} \mathrm{K})-\left(\mathrm{mEq} \mathrm{Cl}+\mathrm{mEq} \mathrm{SO}_{4}\right)$.

${ }^{6}$ Calculated MP based on $13.0 \mathrm{~kg}$ of DMI/d (NRC, 2001).

${ }^{7}$ Calculated absorbable $\mathrm{Ca}$ at intake of $13.0 \mathrm{~kg}$ of DMI/d (NRC, 2001). space per cow and less than $85 \%$ stocking density of freestalls. After d 10, cows were moved to the larger lactating pens of the farm.

Heparinized blood samples were obtained from each cow at least once per week for the 3 wk before calving. Beginning approximately 1 wk before expected calving, cows were bled daily. Most of the cows were bled within $1 \mathrm{~h}$ after calving, and this time point is referred to as time 0 in the study. For a few cows that calved between 2300 and $0400 \mathrm{~h}$, the first blood sample after calving, time 0 , was taken no more than $5 \mathrm{~h}$ after calving. Blood was also sampled at $0.5,1,1.5,2,2.5,3,3.5,4$, and 10 $\mathrm{d}$ after calving. Blood $\mathrm{Ca}$ and $\mathrm{Mg}$ concentrations were determined by inductively coupled plasma MS (VarianAgilent ICP-MS, Santa Clara, CA) on plasma samples diluted 1:25 with $1 \%$ nitric acid. Plasma inorganic P concentration was determined by reaction with acidic ammonium molybdate (Amador and Urban, 1972). Urine samples were obtained by manually stimulating micturition several times before calving from each cow, and urine $\mathrm{pH}$ was determined within $1 \mathrm{~h}$ using a calibrated $\mathrm{pH}$ meter (Fisher Scientific, Waltham, MA). The $\mathrm{pH}$ value of the sample obtained closest to parturition was used in determining the mean effect of diet on urine pH. Body condition score (5 point scale; Ferguson et al., 1994) was recorded at 1 to 2 wk pre-calving.

\section{Rumination Monitoring}

The rumination monitoring system used a neck collar to hold an accelerometer over the left lateral pharyngeal area (HR LD tag; SCR Dairy, Netanya, Israel). Raw data were interpreted by an algorithm developed by SCR Dairy as minutes spent ruminating during 2 -h periods. These data were summed to determine minutes spent ruminating per $6 \mathrm{~h}(0.25 \mathrm{~d})$ or $24 \mathrm{~h}(1 \mathrm{~d})$ before or after calving. The metal neck collar weight designed to keep the HR tag and collar in place activated the Calan gates and was replaced with a sand bag of similar weight. The collar was also taped to the poll area of a halter on the cow to help keep it in place. Each cow also wore a rope collar with the assigned Calan gate key. Data from the rumination monitoring system were collected wirelessly in an adjacent barn.

\section{Statistical Analyses}

One cow assigned to the control diet gave birth to stillborn twins 3 wk before she was due to calve and was removed from the study. One cow in each diet treatment group delivered twins, and their data are included.

Pearson's product moment correlations were calculated to determine the relationship between blood $\mathrm{Ca}$ 
concentration in the middle of a 24 -h period just before and after calving and rumination activity on the days (24-h periods) before and after calving. We assessed the effects of $\mathrm{Ca}$ status and diet on plasma $\mathrm{Ca}, \mathrm{Mg}$, $\mathrm{P}$, DMI, and rumination activity using the MIXED procedure in SAS 7.1 (SAS Inc., Cary, NC). The Ca status of the cows was used to categorize them as having normocalcemia, subclinical hypocalcemia, or clinical hypocalcemia (milk fever). Four cows that received the control diet developed clinical hypocalcemia and were categorized as having milk fever in all models. Several definitions of normocalcemic were evaluated in statistical models.

Model 1. Cows were considered normocalcemic if their blood Ca remained above $2.00 \mathrm{mM}(8.0 \mathrm{mg} / \mathrm{dL})$ in all blood samples. Cows without milk fever but with at least 1 blood sample with a Ca concentration below $2.00 \mathrm{~m} M$ were classified as having subclinical hypocalcemia.

Model 2. Cows were considered normocalcemic if their blood Ca remained above $1.75 \mathrm{mM}(7.5 \mathrm{mg} / \mathrm{dL})$ in all blood samples. Cows without milk fever but with at least 1 blood sample with a Ca concentration below $1.75 \mathrm{~m} M$ were classified as having subclinical hypocalcemia.

Model 3. Cows were considered normocalcemic if their blood $\mathrm{Ca}$ concentration at the 36 -h time point or later remained above $2.00 \mathrm{~m} M$. Cows without milk fever but with at least 1 blood sample with a Ca concentration below $2.00 \mathrm{mM}$ at the 36 -h time point or later were classified as having subclinical hypocalcemia.

Model 4. Cows were categorized by diet and then by clinical status as cows with or without milk fever. None of the cows fed the low DCAD diet developed milk fever.

Model Effects. One of the main effects included in the models was Ca status (normocalcemia, subclinical hypocalcemia, or milk fever), or diet/clinical status (low DCAD, control without milk fever, control with milk fever). The other main effect in all models was day around calving. The model also included interactions between the main effects. Cow nested within Ca status or diet/clinical status was the subject, and day around calving was the repeated measure. An autoregressive covariance structure was used because it yielded the Akaike information criterion that was closest to zero (Littell et al., 1998). When tests of fixed effects indicated a significant effect at $P<0.10$, post hoc pairwise testing of differences between least squares means at each day was performed using the Slice option in SAS and the Tukey adjustment for the number of tests performed. Data on BCS, $4 \mathrm{~d}$ total milk production, and urine $\mathrm{pH}$ before calving were compared using Student's t-test.

\section{RESULTS AND DISCUSSION}

\section{Cow Attributes}

Cows were fed the control diet for $21.3 \pm 1.7 \mathrm{~d}$ or the low DCAD diet for $21.2 \pm 1.3 \mathrm{~d}$ before calving [mean \pm standard error of the mean (SEM)]. Urine $\mathrm{pH}$ measured in the week before calving for cows fed the control diet $(8.26 \pm 0.06)$ was significantly greater than in cows fed the low DCAD diet $(6.93 \pm 0.17 ; P<$ $0.0001)$. Cows' parity $(3.58 \pm 0.23$ for control and 3.46 \pm 0.22 for low DCAD) and BCS before calving (3.13 \pm 0.06 for control and $3.17 \pm 0.07$ for low DCAD) did not differ across the diet treatments. Three control cows and 2 cows fed the low DCAD diet did not complete their lactations because they were culled after developing mastitis or lameness, which occurred beyond the first 20 DIM. Cows fed the control and low DCAD diets produced similar amounts of milk during the first $4 \mathrm{~d}$ of lactation $(96.3 \pm 4.6$ and $108.0 \pm 5.5 \mathrm{~kg}$, respectively; $P=0.12)$.

Four of the control cows developed severe hypocalcemia and became recumbent. They were diagnosed as having milk fever, confirmed by blood Ca concentration below $1.25 \mathrm{mM}$ before intravenous treatment with 500 $\mathrm{mL} 23 \%$ Ca gluconate (Durvet, Blue Springs, MO). Two of the cows with milk fever received an oral Ca bolus (Transition Bolus; MAI, Spring Valley, WI) 12 to $24 \mathrm{~h}$ after intravenous Ca treatment, because clinical examination suggested they were again developing severe hypocalcemia. Data from these cows are included in treatment means, but blood Ca concentrations determined within $10 \mathrm{~h}$ of intravenous or oral Ca treatment were excluded from plasma Ca concentration means used in the statistical analysis.

\section{Effects of Ca Status}

Correlations Between Hypocalcemia and Rumination Activity. Plasma Ca concentration during the middle of the first day of lactation $(0.5 \mathrm{~d})$ was highly correlated with rumination rate on the first day of lactation, when many cows were hypocalcemic $(\mathrm{r}=$ 0.75, $P<0.001$; Figure 1A). Plasma Ca concentration at time $0.5 \mathrm{~d}$ was also correlated with rumination rate on the second day after calving, even though blood $\mathrm{Ca}$ concentrations had increased in most cows by d $2(\mathrm{r}=$ $0.68, P<0.001 ;$ Figure 1B). The correlation between rumination rate on d 2 (the second 24-h after calving) and plasma Ca concentration at $1.5 \mathrm{~d}$ after calving was not as strong $(\mathrm{r}=0.35, P<0.08$; Figure $1 \mathrm{C})$. These data suggest that hypocalcemia on the first day of lactation and its attendant effect on other factors such as DMI may have persistent effects on rumination activity. 

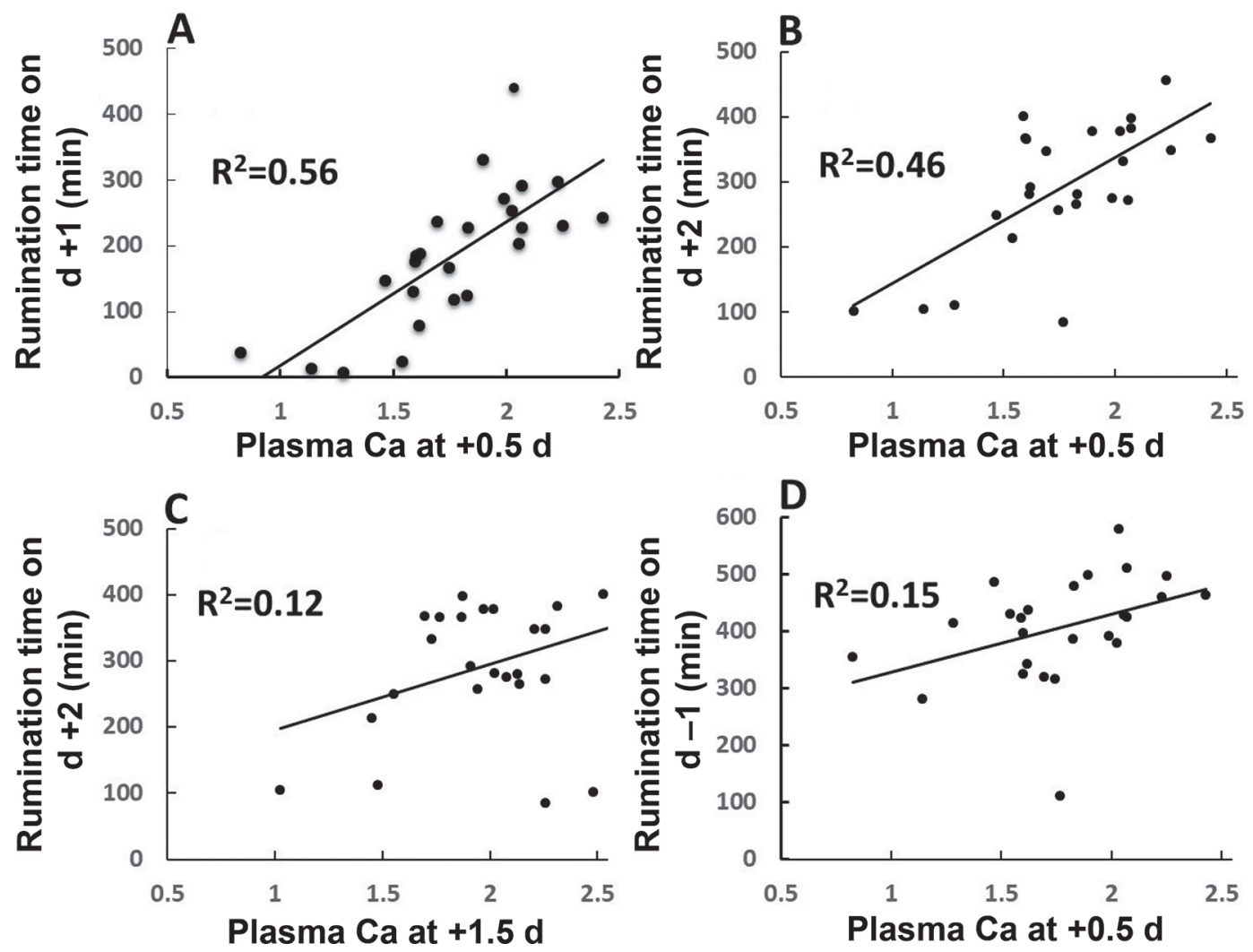

Figure 1. Correlations between plasma Ca concentration $(\mathrm{m} M)$ and rumination rate expressed in minutes spent ruminating per day. (A) Correlation between plasma Ca concentration at the midpoint of $\mathrm{d} 1$ of lactation $(+0.5 \mathrm{~d}$ blood sample) and rumination rate on $\mathrm{d} 1$ of lactation $(\mathrm{r}=0.75, P<0.001)$; (B) correlation between plasma Ca concentration at the midpoint of $\mathrm{d} 1$ of lactation $(+0.5 \mathrm{~d}$ blood sample) and rumination rate on $\mathrm{d} 2$ of lactation $(\mathrm{r}=0.68, P<0.001)$; $(\mathrm{C})$ correlation between plasma Ca concentration at the midpoint of $\mathrm{d} 2$ of lactation $(+1.5 \mathrm{~d}$ blood sample) and rumination rate on $\mathrm{d} 2$ of lactation $(\mathrm{r}=0.35, P<0.10)$; (D) correlation between plasma Ca concentration at the midpoint of $\mathrm{d} 1$ of lactation $(+0.5 \mathrm{~d}$ blood sample) and rumination rate on the day before calving $(\mathrm{r}=0.39, P<0.05)$.

Liboreiro et al. (2015) found only a weak correlation $(\mathrm{r}=0.15)$ between periparturient hypocalcemia and daily rumination rate. However, they used only a single blood sample obtained at some point in a 3 -d period after calving to assess the Ca status of an individual cow. Paudyal et al. (2018) developed an index based on rumination activity in an individual cow around the time of calving relative to herd mates. This index was able to detect cows with clinical hypocalcemia (milk fever) with $100 \%$ sensitivity and $85 \%$ specificity. Subclinical hypocalcemia was not examined in that study.

Rumination rate can be used to predict the development of metritis and metabolic disease, such as ketosis and displacement of the abomasum, because these disorders cause depression of the rumination rate 1 to $2 \mathrm{~d}$ before the onset of clinical signs diagnosed by human observers (Kaufman et al., 2016; Stangaferro et al., 2016). In Figure 1D, the correlation between rumination rate during the $24 \mathrm{~h}$ before calving and plasma Ca concentration at time $0.5 \mathrm{~d}$ was significant, but not strong $(\mathrm{r}=0.39, P<0.05)$, suggesting that rumina- tion activity before calving was unlikely to be a robust means of predicting later development of hypocalcemia.

Rumination activity decreased significantly in our cows around the time of calving. Soriani et al. (2012) observed a $70 \%$ decline in rumination activity at parturition. In a study by Pahl et al. (2014), cows stopped ruminating about $2 \mathrm{~h}(123 \pm 58 \mathrm{~min})$ before calving and resumed about $6 \mathrm{~h}(355 \pm 194 \mathrm{~min})$ after calving. The act of parturition alone likely causes pain and distraction as a result of attending to the calf, which seems to prevent most cows from eating or ruminating for several hours immediately before and after calving.

Effect of Milk Fever on Rumination. Figure 2 presents plasma $\mathrm{Ca}$ concentrations and rumination activity in 2-h periods around the time of calving in the 4 cows on the control diet that developed clinical hypocalcemia (milk fever). All 4 responded to intravenous Ca treatment by standing and walking again within 20 min after treatment. Rumination activity was very low or nondetectable in these cows before and after treatment for an extended period, despite clinical recovery 

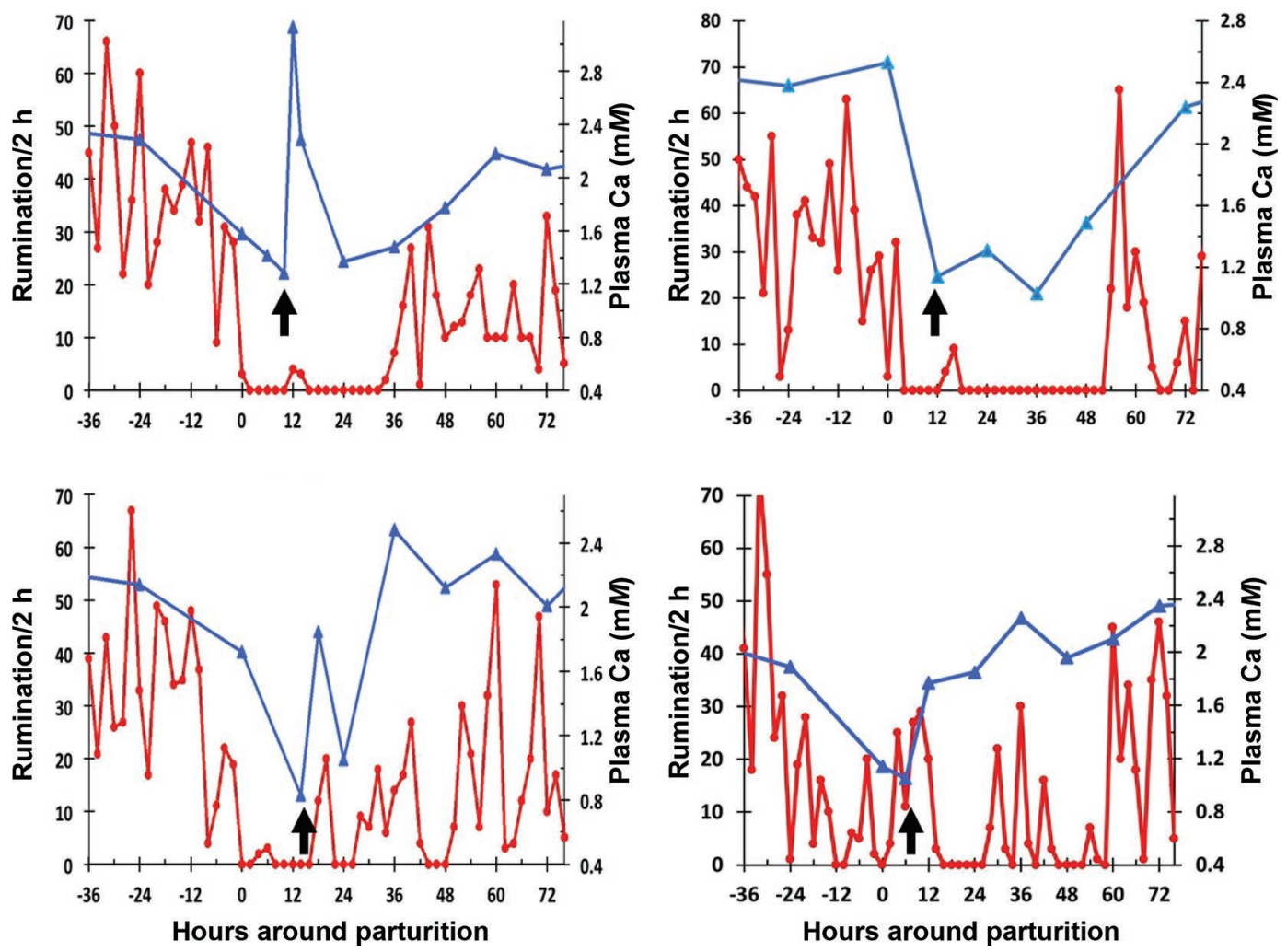

Figure 2. Plasma Ca concentration ( $\mathrm{m} M ; \boldsymbol{\Delta})$ and rumination rate expressed in minutes spent ruminating per 2-h period (•) in 4 cows fed the control diet that developed milk fever. The black arrow indicates the time at which each cow received an intravenous infusion of Ca to treat milk fever.

of skeletal and smooth muscle function (observed as regaining the ability to stand and to eructate). Two of the 4 cows exhibited no rumination activity for up to $36 \mathrm{~h}$ after calving. In 3 of the 4 cows, intravenous administration of $\mathrm{Ca}$, which raises blood $\mathrm{Ca}$ to normal or higher levels for up to $6 \mathrm{~h}$ after treatment (Goff, 1999), caused only a small increase in rumination rate that was sustained for just 2 to $6 \mathrm{~h}$ after treatment. Unlike rumen motility (Daniel, 1983), rumination (as indicated by the rate of mastication detected by the accelerometers) was not restored simply by improving the blood Ca concentration of the cows with milk fever.

Effect of Subclinical Hypocalcemia on Rumination. Subclinical hypocalcemia has been linked to an increased risk of development of several health disorders in the periparturient cow (Martinez et al., 2012; Neves et al., 2018). However, the blood Ca concentration that defines normocalcemia is controversial. Reinhardt et al. (2011) suggested that cows with blood Ca above $2 \mathrm{mM} / \mathrm{L}$ during the first $36 \mathrm{~h}$ after calving were normocalcemic, and Martinez et al. (2012) suggested that cows should have blood Ca above $2.15 \mathrm{mM}$ in the first $3 \mathrm{~d}$ of lactation to be considered normocalcemic. We used various criteria to categorize cows in our study as normocalcemic or subclinically hypocalcemic based on periparturient blood Ca concentrations. The results of 3 of these statistical models are presented below.

In model 1, normocalcemia was defined as a blood Ca concentration above $2.00 \mathrm{~m} M$ in all blood samples taken. Only 4 cows in the present study (all fed the low DCAD diet) had blood Ca above $2.00 \mathrm{~m} M$ in all blood samples obtained. Four cows developed clinical hypocalcemia (milk fever), and 17 cows were classified as having subclinical hypocalcemia. Perhaps because of the age of the cows in our study, none of them could be considered normocalcemic using the criteria of Martinez et al. (2012). The nadir in plasma Ca concentration for the 4 normocalcemic cows occurred at the time of calving and was $2.09 \mathrm{mM}$. The subclinically hypocalcemic cows and cows with milk fever had plasma Ca nadirs of 1.74 and $1.08 \mathrm{mM}$, respectively, and these were reached later, at 24 and $12 \mathrm{~h}$ after calving, respectively (Figure 3A). Plasma Ca concentrations in subclinically hypocalcemic cows were lower than in normocalcemic cows from the time of calving through the first $2 \mathrm{~d}$ of lactation $(P<0.05)$. In this model, the subclinically hypocalcemic cows ruminated 77 min less on $\mathrm{d} 1$ after calving than the normocalcemic cows $(P=0.075)$ and 
50 min less on d $2(P=0.23$; Figure $3 \mathrm{~B})$. Dry matter intake was similar in normocalcemic and subclinically hypocalcemic cows. The cows with milk fever (in this model and all statistical models described below) had significantly reduced plasma Ca concentrations, rumination rate, and DMI compared to normocalcemic and subclinically hypocalcemic cows on $\mathrm{d} 1,2$, and 3 of lactation $(P<0.01)$.
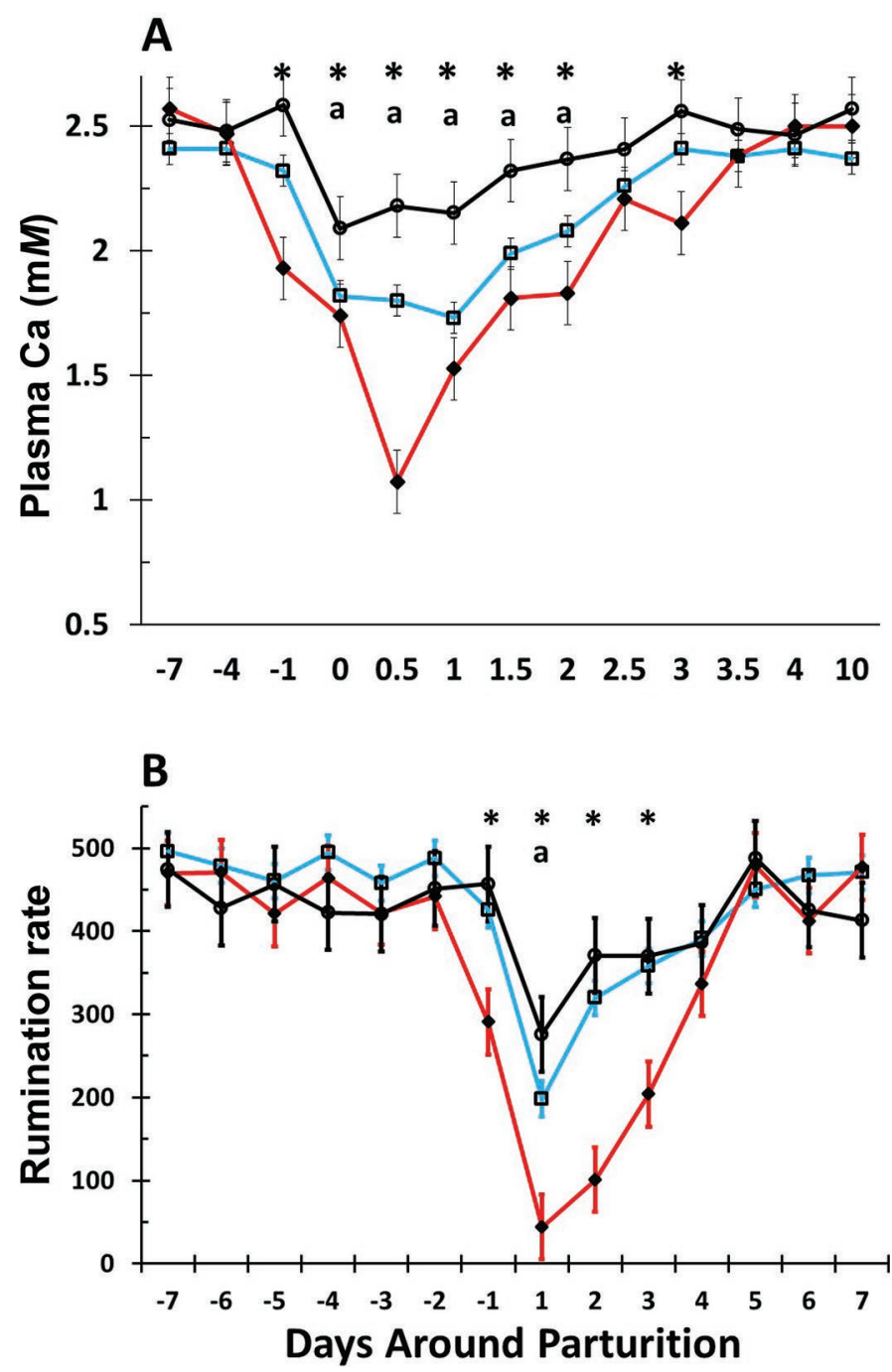

Figure 3. (A) Mean \pm SEM plasma Ca concentration $(\mathrm{m} M)$ and (B) rumination rate, expressed as minutes spent ruminating per day, in cows classified as normocalcemic, subclinically hypocalcemic, or having milk fever. Cows were considered normocalcemic if all plasma samples obtained had a Ca concentration of at least $2.00 \mathrm{~m} M$. Normocalcemic cows $(n=4)$ are designated by white circles, subclinically hypocalcemic cows $(n=17)$ by white squares, and cows with milk fever $(\mathrm{n}=4)$ by black diamonds. ${ }^{*}$ Indicates a significant difference between normocalcemic cows and cows with milk fever at that time point $(P<0.05)$. ${ }^{a}$ Indicates a significant difference between normocalcemic cows and subclinically hypocalcemic cows at that time point $(P<0.075)$.
In model 2, a normocalcemic cow was defined as a cow with blood Ca concentration greater than $1.75 \mathrm{mM}$ in all blood samples taken. This caused 7 of 13 cows on the low DCAD diet and 2 of 8 cows on the control diet to be classified as normocalcemic. Four cows on the control diet developed milk fever, and the remaining 12 cows in the study were classified as subclinically hypocalcemic. In this model, the rumination rate of subclinically hypocalcemic cows was numerically lower, but not significantly lower, than that of normocalcemic cows $(P=0.15)$. Dry matter intake was statistically similar in normocalcemic and subclinically hypocalcemic cows.

Many multiparous cows will be categorized as subclinically hypocalcemic when the criteria for normocalcemia is a blood Ca concentration greater than $2.00 \mathrm{~m} M$ (Leno et al., 2017). A certain degree of hypocalcemia on d 1 of lactation is associated with higher milk production and is the stimulus for Ca homeostasis responses (Blanc et al., 2014; McArt and Neves, 2020). However, prolonged hypocalcemia (beyond the first day of lactation) may be of greater consequence to the cow's health and productivity (Caixeta et al., 2017; Neves et al., 2018). In model 3, we considered the effect of hypocalcemia beyond the first day of lactation. Cows were categorized as normocalcemic if their blood Ca concentration remained above $2.00 \mathrm{mM}$ at $36 \mathrm{~h}$ or later. Two of the 8 cows on the control diet and 11 of 13 cows on the low DCAD diet were considered normocalcemic by this definition. The remaining 8 cows that did not develop milk fever were classified as subclinically hypocalcemic. The cows classified as subclinically hypocalcemic using these criteria had significantly lower plasma Ca at the 0-, 12-, 24-, and 36-h time points compared with normocalcemic cows. In this model, the rumination rate and DMI of cows with subclinical hypocalcemia were numerically lower, but not significantly lower, than those of normocalcemic cows.

Rumination rate is directly correlated with plasma Ca status. Clinical hypocalcemia or milk fever has profound effects on rumination rate. It was not possible with this data set to define a Ca concentration for subclinical hypocalcemia that clearly indicated that rumination rate would be compromised compared with normocalcemic cows. The effect of plasma Ca concentration on rumination rate is a continuous linear effect, and it seems that any decline in plasma Ca concentration is associated with reduced rumination rate (Figure 1). The degree of hypocalcemia experienced by the cows with milk fever was substantially greater and of longer duration than in normocalcemic or subclinically hypocalcemic cows, also causing a markedly large difference in rumination rate. Using this limited data set, any cow with a rumination rate below $140 \mathrm{~min} / \mathrm{d}$ should be suspected of having pronounced hypocalcemia in the first 
days of lactation. Rumination rate began to decrease before calving in the cows with milk fever and even the cows with subclinical hypocalcemia. However, the magnitude of this decline in rumination rate could be difficult for the herd manager to differentiate from the decrease in rumination rate associated with the onset of parturition.

Effect of Diet DCAD. None of the cows fed the low DCAD diet developed milk fever. Cows with milk fever have severe hypocalcemia and severely compromised rumination. Therefore, in model 4 , cows fed the control diet were further categorized as control cows with or without milk fever. The cows on the control diet that developed milk fever had reduced plasma $\mathrm{Ca}$ concentration and a lower rumination rate the first $3 \mathrm{~d}$ of lactation compared with cows on the low DCAD diet $(P<0.001$; Figure 4A and B). Cows with milk fever had significantly reduced DMI during the first $2 \mathrm{~d}$ of lactation compared with cows on the low DCAD diet (Figure 5). Plasma Ca concentrations in cows on the low DCAD cows were significantly greater than those in control cows without milk fever, from calving to $36 \mathrm{~h}$ after calving $(P<0.025)$. Rumination rate was greater in cows on the low DCAD diet than in control cows without milk fever on the day before calving $(457 \pm 26$ vs. $389 \pm 32 \mathrm{~min} / \mathrm{d} ; P=0.104)$ and on the first day of lactation $(248 \pm 26$ vs. $158 \pm 32 \mathrm{~min} / \mathrm{d} ; P=0.034)$. Control cows without milk fever returned to $90 \%$ of pre-calving rumination rate on $\mathrm{d} 5$, and cows on the low DCAD diet reached $90 \%$ of pre-calving rumination rate by d 4 (Figure $4 \mathrm{~B}$ ).

In Figure $4 \mathrm{C}$, rumination rate is also presented in 0.25 $\mathrm{d}$ increments before and after calving. The rumination rate of cows on the low DCAD diet was significantly greater than in control cows without milk fever from 0.25 through $0.75 \mathrm{~d}$ after calving and again from 1.5 to $1.75 \mathrm{~d}$ after calving. This seemed to reflect plasma $\mathrm{Ca}$ concentration. Mean plasma $\mathrm{Ca}$ in the control cows without milk fever was below $1.75 \mathrm{~m} M$ at $0,0.5$, and $1 \mathrm{~d}$ after calving, and below $1.87 \mathrm{~m} M$ at $1.5 \mathrm{~d}$; mean plasma $\mathrm{Ca}$ in cows on the low DCAD diet was above $2.00 \mathrm{mM}$ at all time points except for $24 \mathrm{~h}$.

Dry matter intake before calving was similar in cows fed the low DCAD and control diets (Figure 5). Control cows that did not develop milk fever and cows fed the low DCAD diet reached their nadir in DMI the day before calving, but had a similar DMI in the first $5 \mathrm{~d}$ of lactation. Control cows that did develop milk fever had a significantly lower DMI than cows fed the low DCAD diet in the first $3 \mathrm{~d}$ of lactation $(P<0.003)$. Metz (1975) observed that each kilogram decrease in DMI was associated with a reduction of $44 \mathrm{~min} / \mathrm{d}$ in rumination activity. Hypocalcemia may directly affect the hypothalamic satiety and feeding centers affecting DMI.
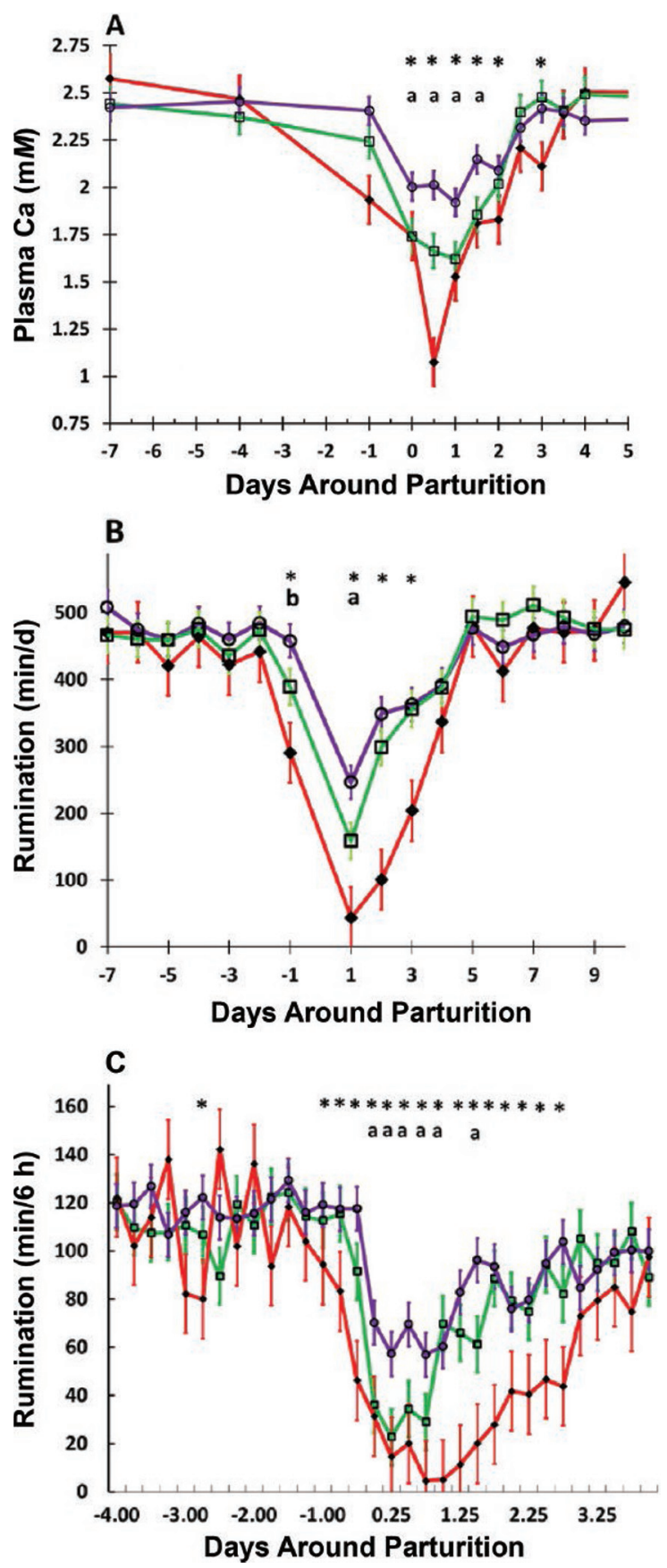

Figure 4. (A) Mean \pm SEM plasma Ca concentration $(\mathrm{m} M)$ and rumination rate, expressed as (B) minutes spent ruminating per day or (C) minutes spent ruminating per 6-h period, in cows classified based on diet and whether they developed milk fever. Milk fever did not occur in any cows on the low DCAD diet. Cows on the low DCAD $(\mathrm{n}=13)$ are designated by white circles, cows on the control diet that did not develop milk fever $(n=8)$ by white squares, and cows on the control diet that developed milk fever $(\mathrm{n}=4)$ by black diamonds. *Indicates a significant difference between cows on the low DCAD diet and cows on the control diet that developed milk fever at that time point $(P<0.05)$. ${ }^{\text {and }}$ Incates a significant difference between cows on the low DCAD diet and cows on the control diet that did not develop

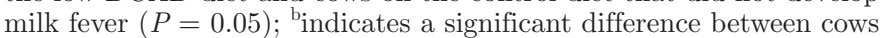
on the low DCAD diet and cows on the control diet that did not develop milk fever $(P=0.106)$. 


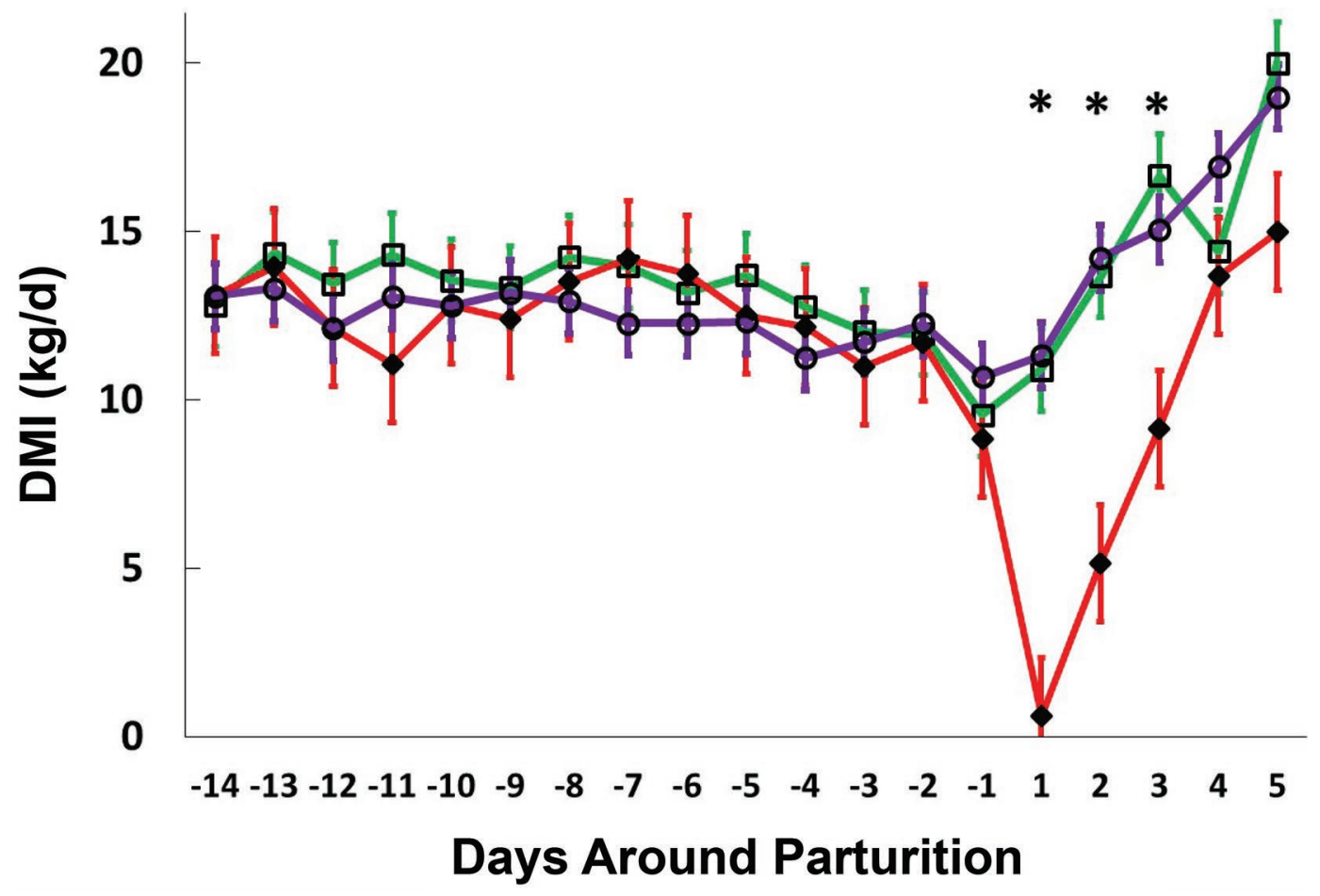

Figure 5. Mean \pm SEM DMI $(\mathrm{kg} / \mathrm{d})$ in periparturient cows classified based on diet and whether they developed milk fever. None of the cows on the low DCAD diet developed milk fever. Cows on the low DCAD $(\mathrm{n}=13)$ are designated by white circles, cows on the control diet that did not develop milk fever $(\mathrm{n}=8)$ by white squares, and cows on the control diet that developed milk fever $(\mathrm{n}=4)$ by black diamonds. ${ }^{*}$ Indicates a significant difference between cows on the low DCAD diet and cows on the control diet that developed milk fever at that time point $(P<0.003)$.

Alternatively, the reduction in DMI, particularly in the cows with milk fever, may allow the forage particles in the rumen to diminish below the point where they successfully stimulate afferent fibers in the rumen wall to initiate rumination activity. We included high amounts of straw in the diet, believing this would allow some fiber to persist in the rumen mat and provide stimulation of rumen wall afferent neurons, even when DMI was depressed (Van Soest, 1994). However, because we did not open the rumens of the cows to examine the rumen mat, we cannot state whether hypocalcemia, independent of lack of effective fiber in the rumen, was the sole cause of decreased rumination activity in the cows with milk fever.

Other Diet Effects. Plasma Mg concentrations increased in all cows at the time of calving, but the increase in blood $\mathrm{Mg}$ was significantly greater in cows fed the control diet at calving and through the first $24 \mathrm{~h}$ of lactation. The lower plasma $\mathrm{Ca}$ concentrations in the control cows likely caused greater parathyroid hormone secretion. Parathyroid hormone stimulates greater reabsorption of $\mathrm{Mg}$ from the renal tubular fluid, increasing plasma $\mathrm{Mg}$ concentration (Goff, 2014). The effect of diet $x$ day interactions on plasma iP was significant $(P<0.05)$. Cows fed the low DCAD diet had higher plasma $\mathrm{P}$ concentrations at $-1,0.5,1$, and $1.5 \mathrm{~d}$ around parturition. Parathyroid hormone, secreted in response to hypocalcemia, increases salivary $\mathrm{P}$ secretion (Wright et al., 1984), and reduced rumen motility caused by hypocalcemia sequesters $\mathrm{P}$ in the rumen until the hypocalcemia is corrected (Goff, 2000).

Metabolic alkalosis caused by consumption of a diet high in absorbable cations interferes with the ability of tissues such as bone and kidney to respond to parathyroid hormone. This prevents successful Ca homeostasis in some cows (Goff et al., 2014). The DCAD of the low DCAD diet in this study, which successfully prevented milk fever and reduced hypocalcemia, was just $-9 \mathrm{mEq} /$ $\mathrm{kg}$ of DM $(-0.9 \mathrm{mEq} / 100 \mathrm{~g} \mathrm{DM})$. It may only be necessary to bring the cow away from a state of metabolic alkalosis to restore parathyroid hormone sensitivity in the tissues. This study could not define the DCAD at which Ca homeostasis is optimal, but it suggested that it is not necessary to have a much lower diet DCAD to positively affect the blood Ca status of the periparturient cow. Perhaps the $\mathrm{P}$ concentration of the diet $(0.24-$ $0.25 \%$ ) potentiated the ability of this moderately low DCAD $(-9 \mathrm{mEq} / \mathrm{kg})$ diet to improve Ca homeostasis (Barton et al., 1987; Kichura et al., 1982; Peterson et al., 2005). Feeding higher prepartal diet $\mathrm{P}$ may raise 
blood iP concentration, which in turn can cause bone osteocytes to react by secreting fibroblast growth factor 23. This bone hormone inhibits the synthesis of renal 25-hydroxyvitamin D 1- $\alpha$-hydroxylase, the enzyme that converts 25-hydroxyvitamin $\mathrm{D}$ to the hormone 1,25-dihydroxyvitamin D (Martin and Quarles, 2012). This, in turn, reduces blood iP concentration because 1,25-dihydroxyvitamin D normally stimulates intestinal $\mathrm{P}$ absorption. Although it is integral to $\mathrm{P}$ homeostasis, inhibiting 1,25-dihydroxyvitamin $\mathrm{D}$ production interferes with the ability of the cow to upregulate intestinal Ca transporters, compromising Ca homeostasis (Cohrs et al., 2018). Mean blood iP concentrations before calving in all cows were within normal limits (1.29-1.93 $\mathrm{m} M$; 4-6 mg of iP/dL; Goff, 1999), indicating that the $0.24 \% \mathrm{P}$ diet met the cows' $\mathrm{P}$ requirement, corroborating the NRC (2001) model and the findings of Peterson et. al. (2005).

\section{CONCLUSIONS}

Before calving, cows in their third parity or greater were fed a diet to induce hypocalcemia or the same diet with added anions to reduce hypocalcemia, resulting in a large range of postpartum blood Ca concentrations. Using a rumination monitoring system based on accelerometer technology, we observed a strong correlation between blood $\mathrm{Ca}$ concentrations $0.5 \mathrm{~d}$ after calving and rumination activity on the first and second days of lactation. Using several definitions of normocalcemia, cows were classified retrospectively as having normocalcemia, subclinical hypocalcemia, and milk fever. Subclinical hypocalcemia reduced rumination rate numerically, but this finding was statistically significant only when normocalcemia was defined as a plasma Ca above $8.0 \mathrm{mg} / \mathrm{dL}$ in all samples and only on the first day of lactation. Four cows fed the control diet developed milk fever, which caused cessation of rumination for as long as 36 h. Diet affected rumination rate. On d 1 of lactation, cows fed the low DCAD diet ruminated 86 min longer than cows fed the control diet that did not develop milk fever, and 124 min longer than cows fed the control diet that developed milk fever on $\mathrm{d} 1$ of lactation. Cows with milk fever had significantly reduced rumination rate and DMI compared with cows fed the low DCAD diet until d 4 of lactation.

\section{ACKNOWLEDGMENTS}

The authors acknowledge Landus Cooperative (Ames, IA) for providing the anion supplement and control supplement used in the trial, and for providing monies to support graduate student Hohman and provide hourly wages for the following Iowa State University veterinary medical students who assisted with the care of the cows: Alexis Hytry, Mikalah Smith, Isaac Fisher, Sierra Phillip, and Austin Ashbacher. The authors thank the staff of the Iowa State University Dairy for the use of the animals, and for their help with this project. Thanks also to Catherine Martens (Biomedical Sciences, Iowa State University, Ames) for technical help in the laboratory. J. P. Goff serves as a consultant for Landus Cooperative (Ames, IA).

\section{REFERENCES}

Amador, E., and J. Urban. 1972. Simplified serum phosphorus analyses by continuous-flow ultraviolet spectrophotometry. Clin. Chem. 18:601-604.

Bae, D. H., J. G. Welch, and B. E. Gilman. 1983. Mastication and rumination in relation to body size of cattle. J. Dairy Sci. 66:21372141. https://doi.org/10.3168/jds.S0022-0302(83)82060-8.

Barton, B. A., N. A. Jorgensen, and H. F. DeLuca. 1987. Impact of prepartum dietary phosphorus intake on Ca homeostasis at parturition. J. Dairy Sci. 70:1186-1191. https://doi.org/10.3168/jds .S0022-0302(87)80130-3.

Blanc, C. D., M. Van der List, S. S. Aly, H. A. Rossow, and N. Silvadel-Río. 2014. Blood calcium dynamics after prophylactic treatment of subclinical hypocalcemia with oral or intravenous calcium. J. Dairy Sci. 97:6901-6906. https://doi.org/10.3168/jds.2014-7927.

Caixeta, L. S., P. A. Ospina, M. B. Capel, and D. V. Nydam. 2017. Association between subclinical hypocalcemia in the first 3 days of lactation and reproductive performance of dairy cows. Theriogenology 94:1-7. https://doi.org/10.1016/j.theriogenology.2017.01 .039 .

Castilla-Guerra, L., M. C. Fernández-Moreno, J. M. López-Chozas, and R. Fernández-Bolaños. 2006. Electrolytes disturbances and seizures. Epilepsia 47:1990-1998. https://doi.org/10.1111/j.1528 $-1167.2006 .00861 . x$.

Cohrs, I., M. R. Wilkens, and W. Grünberg. 2018. Short communication: Effect of dietary phosphorus deprivation in late gestation and early lactation on the calcium homeostasis of periparturient dairy cows. J. Dairy Sci. 101:9591-9598. https://doi.org/10.3168/ jds.2018-14642.

Daniel, R. C. 1983. Motility of the rumen and abomasum during hypocalcaemia. Can. J. Comp. Med. 47:276-280.

Ferguson, J. D., D. T. Galligan, and N. Thomsen. 1994. Principal descriptors of body condition score in Holstein cows. J. Dairy Sci. 77:2695-2703. https://doi.org/10.3168/jds.S0022-0302(94)77212 $-\mathrm{X}$.

Goff, J. P. 1999. Treatment of calcium, phosphorus, and magnesium balance disorders. Vet. Clin. North Am. Food Anim. Pract. 15:619-639. https://doi.org/10.1016/S0749-0720(15)30167-5.

Goff, J. P. 2000. Pathophysiology of calcium and phosphorus disorders. Vet. Clin. North Am. Food Anim. Pract. 16:319-337. https:/ /doi.org/10.1016/S0749-0720(15)30108-0.

Goff, J. P. 2014. Calcium and magnesium disorders. Vet. Clin. North Am. Food Anim. Pract. 30:359-381. https://doi.org/10.1016/j .cvfa.2014.04.003

Goff, J. P., M. E. Kehrli Jr., and R. L. Horst. 1989. Periparturient hypocalcemia in cows: Prevention using intramuscular parathyroid hormone. J. Dairy Sci. 72:1182-1187.

Goff, J. P., and N. J. Koszewski. 2018. Comparison of $0.46 \%$ calcium diets with and without added anions with a $0.7 \%$ calcium anionic diet as a means to reduce periparturient hypocalcemia. J. Dairy Sci. 101:5033-5045. https://doi.org/10.3168/jds.2017-13832.

Goff, J. P., A. Liesegang, and R. L. Horst. 2014. Diet-induced pseudohypoparathyroidism: A hypocalcemia and milk fever risk factor. J. Dairy Sci. 97:1520-1528. https://doi.org/10.3168/jds.2013-7467.

Han, P., B. J. Trinidad, and J. Shi. 2015. Hypocalcemia-induced seizure: Demystifying the calcium paradox. ASN Neuro. 7:1-9. https: //doi.org/10.1177/1759091415578050. 
Hansen, S. S., P. Nørgaard, C. Pedersen, R. J. Jørgensen, L. S. Mellau, and J. D. Enemark. 2003. The effect of subclinical hypocalcaemia induced by Na2EDTA on the feed intake and chewing activity of dairy cows. Vet. Res. Commun. 27:193-205. https://doi.org/10 .1023/A:1023340506782.

Jørgensen, R. J., N. R. Nyengaard, S. Hara, J. M. Enemark, and P. H. Andersen. 1998. Rumen motility during induced hyper- and hypocalcaemia. Acta Vet. Scand. 39:331-338.

Kaufman, E. I., S. J. LeBlanc, B. W. McBride, T. F. Duffield, and T. J. DeVries. 2016. Association of rumination time with subclinical ketosis in transition dairy cows. J. Dairy Sci. 99:5604-5618. https: //doi.org/10.3168/jds.2015-10509.

Kichura, T. S., R. L. Horst, D. C. Beitz, and E. T. Littledike. 1982. Relationships between prepartal dietary calcium and phosphorus, vitamin $\mathrm{D}$ metabolism, and parturient paresis in dairy cows. J. Nutr. 112:480-487. https://doi.org/10.1093/jn/112.3.480.

Leno, B. M., C. M. Ryan, T. Stokol, D. Kirk, K. P. Zanzalari, J. D. Chapman, and T. R. Overton. 2017. Effects of prepartum dietary cation-anion difference on aspects of peripartum mineral and energy metabolism and performance of multiparous Holstein cows. J. Dairy Sci. 100:4604-4622. https://doi.org/10.3168/jds.2016-12221.

Liboreiro, D. N., K. S. Machado, P. R. B. Silva, M. M. Maturana, T. K. Nishimura, A. P. Brandao, M. I. Endres, and R. C. Chebel. 2015. Characterization of peripartum rumination and activity of cows diagnosed with metabolic and uterine diseases. J. Dairy Sci. 98:6812-6827. https://doi.org/10.3168/jds.2014-8947.

Littell, R. C., P. R. Henry, and C. B. Ammerman. 1998. Statistical analysis of repeated measures data using SAS procedures. J. Anim. Sci. 76:1216-1231. https://doi.org/10.2527/1998.7641216x.

Martin, A., and L. D. Quarles. 2012. Evidence for FGF23 involvement in a bone-kidney axis regulating bone mineralization and systemic phosphate and vitamin D homeostasis. Adv. Exp. Med. Biol. 728:65-83. https://doi.org/10.1007/978-1-4614-0887-1_4.

Martinez, N., C. A. Risco, F. S. Lima, R. S. Bisinotto, L. F. Greco, E. S. Ribeiro, F. Maunsell, K. Galvão, and J. E. Santos. 2012. Evaluation of peripartal calcium status, energetic profile, and neutrophil function in dairy cows at low or high risk of developing uterine disease. J. Dairy Sci. 95:7158-7172. https://doi.org/10.3168/jds .2012-5812.

McArt, J. A. A., and R. C. Neves. 2020. Association of transient, persistent, or delayed subclinical hypocalcemia with early lactation disease, removal, and milk yield in Holstein cows. J. Dairy Sci. 103:690-701. https://doi.org/10.3168/jds.2019-17191.

Metz, J. H. M. 1975. Time patterns of feeding and rumination in domestic cattle. PhD Dissertation. Agricultural University, Wageningen, the Netherlands.

Neves, R. C., B. M. Leno, K. D. Bach, and J. A. A. McArt. 2018. Epidemiology of subclinical hypocalcemia in early-lactation Holstein dairy cows: The temporal associations of plasma calcium concentration in the first 4 days in milk with disease and milk production. J. Dairy Sci. 101:9321-9331. https://doi.org/10.3168/ jds.2018-14587.

NRC. 2001. Nutrient Requirements of Dairy Cattle. 7th rev. ed. Natl. Acad. Press, Washington, DC.
Pahl, C., E. Hartung, A. Grothmann, K. Mahlkow-Nerge, and A. Haeussermann. 2014. Rumination activity of dairy cows in the 24 hours before and after calving. J. Dairy Sci. 97:6935-6941. https:/ /doi.org/10.3168/jds.2014-8194.

Paudyal, S., F. P. Maunsell, J. T. Richeson, C. A. Risco, D. A. Donovan, and P. J. Pinedo. 2018. Rumination time and monitoring of health disorders during early lactation. Animal 12:1484-1492. https://doi.org/10.1017/S1751731117002932.

Peterson, A. B., M. W. Orth, J. P. Goff, and D. K. Beede. 2005. Periparturient responses of multiparous Holstein cows fed different dietary phosphorus concentrations prepartum. J. Dairy Sci. 88:35823594. https://doi.org/10.3168/jds.S0022-0302(05)73043-5.

Pfannkuche, H., M. Schemann, and G. Gabel. 2002. Ruminal muscle of sheep is innervated by non-polarized pathways of cholinergic and nitrergic myenteric neurones. Cell Tissue Res. 309:347-354. https: //doi.org/10.1007/s00441-002-0554-7.

Reinhardt, T. A., J. D. Lippolis, B. J. McCluskey, J. P. Goff, and R. L. Horst. 2011. Prevalence of subclinical hypocalcemia in dairy herds. Vet. J. 188:122-124. https://doi.org/10.1016/j.tvjl.2010.03.025.

Ruckebusch, Y. 1989. Gastrointestinal motor functions in ruminants. Pages 1225-1283 in Handbook of Physiology. Vol. I. The Gastrointestinal System. S. G. Schultz, J. D. Wood, and B. B. Rauner, ed. Oxford University Press, New York.

SCR Research. 2013. Rumination Monitoring White Paper. SCR Engineers, Netanya, Israel. Accessed Dec. 18, 2019. http://www.de .scrdairy.com/images/PDF/Rum_12_A4_Eng_Nov13_low.pdf.

Soriani, N., E. Trevisi, and L. Calamari. 2012. Relationships between rumination time, metabolic conditions and health status in dairy cows during the transition period. J. Anim. Sci. 90:4544-4554. https://doi.org/10.2527/jas.2011-5064.

Stangaferro, M. L., R. Wijma, L. S. Caixeta, M. A. Al-Abri, and J. O. Giordano. 2016. Use of rumination and activity monitoring for the identification of dairy cows with health disorders: Part I. Metabolic and digestive disorders. J. Dairy Sci. 99:7395-7410. https:// doi.org/10.3168/jds.2016-10907.

Stevens, C. E., and A. F. Sellers. 1959. Studies of the reflex control of the ruminant stomach with special reference to the eructation reflex. Am. J. Vet. Res. 20:461-482.

Van Soest, P. J. 1994. Function of the ruminant forestomach. Pages 236-240 in Nutritional Ecology of the Ruminant. 2nd ed. Cornell University Press, Ithaca, NY.

Webb, R. C. 2003. Smooth muscle contraction and relaxation. Adv. Physiol. Educ. 27:201-206. https://doi.org/10.1152/advances.2003 .27.4.201.

Wright, R. D., J. R. Blair-West, J. F. Nelson, G. W. Tregear, and M. Rosenblatt. 1984. Evaluation of the biological properties of parathyroid hormone and analogues in a vascularly isolated parotid gland-based assay. J. Endocrinol. 102:375-379. https://doi.org/10 $.1677 /$ joe.0.1020375.

\section{ORCIDS}

J. P. Goff ๑ https://orcid.org/0000-0002-7531-7286 